\title{
РЕЗОЛЮЦИЯ ЗАСЕДАНИЯ «СОЮЗА КРИМИНАЛИСТОВ И КРИМИНОЛОГОВ» 4 АПРЕЛЯ 2015 ГОДА ГОРОД МОСКВА МОСКОВСКИЙ ГОСУДАРСТВЕННЫЙ ЮРИДИЧЕСКИЙ УНИВЕРСИТЕТ ИМЕНИ О.Е. КУТАФИНА (МГЮА)
}

\author{
Мацкевич И.М., Антонян Е.А.
}

Аннотация: В резолючии представлены результаты выступлений участников круглого стола на тему «Предупреждение преступности». Представлены обобщенные результаты выступлений, которые отражены в резолюиии. В частности, выступающие сошлись во мнениях по следуюшим вопросам: необходимо продолжить и совершенствовать работу законодателя в части повышения эффективности мер предупреждения преступности, особенно, на стадии исполнения наказания, обратить внимание на низкое качественное проведения профилактических мероприятий; следует пересмотреть современное состояние профилактики правонарушений; стоит уточнить понятие криминологической политики как: систему управленческих мер реализуемых государством в области противодействия преступности, путем правового воздействия на личность, причины и условия, порождающие преступность в целях ее предупреждения; признать необходимость разработать государственной концепции противодействия организованной преступности; обратить внимание на степень согласованности криминальных и социальных отраслей права в сфере предупреждения преступлений разработать оптимальную криминологическую модель, способную нейтрализовать негативные процессы криминализации общественных отношений.; считать обязательным проведение криминологической экспертизы всех законопроектов, касающихся вопросов противодействия преступности;пересмотреть современное состояние профилактики преступлений; изменить взгляды на проблемы предупреждения преступности. Подписана стенограмма Президентом СКК Мацкевичем И.М.

Ключевые слова: Продолжить, совершенствовать, пересмотреть, изменить, разработать, уточнить, признать, обратить, считать, предлагает.

По итогам докладов Союз криминалистов и криминологов предлагает:

- продолжить и совершенствовать работу законодателя в части повышения эффективности мер предупреждения преступности, особенно, на стадии исполнения наказания, обратить внимание на низкое качественное проведения профилактических мероприятий;

- пересмотреть современное состояние профилактики правонарушений; 
- изменить взгляды на проблемы предупреждения преступности;

- разработать оптимальную криминологическую модель, способную нейтрализовать негативные процессы криминализации общественных отношений.;

- уточнить понятие криминологической политики как: систему управленческих мер реализуемых государством в области противодействия преступности, путем правового воздействия на личность, причины и условия, порождающие преступность в целях ее предупреждения;
- признать необходимость разработать государственной концепции противодействия организованной преступности;

- обратить внимание на степень согласованности криминальных и социальных отраслей права в сфере предупреждения преступлений

- считать обязательным проведение криминологической экспертизы всех законопроектов, касающихся вопросов противодействия преступности;

Президент

Союза криминалистов и криминологов И. М. Мацкевич 